\title{
DHEAS and cortisol correlate with Hypothalamic Serotonin-IA Receptors
}

\author{
Ulrike Moser*1, Wolfgang Wadsak ${ }^{2}$, Patrycja Stein ${ }^{1}$, Christoph Spindelegger ${ }^{1}$, \\ Markus Mitterhauser ${ }^{2,3}$, Alexander Holik ${ }^{1}$, Christian Bieglmayer ${ }^{4}$, \\ Kurt Kletter ${ }^{2}$, Siegfried Kasper ${ }^{1}$ and Rupert Lanzenberger ${ }^{1}$
}

Address: ${ }^{1}$ Department of Psychiatry and Psychotherapy, Medical University of Vienna, Austria, ${ }^{2}$ Department of Nuclear Medicine, PET Centre, Medical University of Vienna, Austria, ${ }^{3}$ Department of Pharmaceutical Technology, University of Vienna, Austria and ${ }^{4} \mathrm{Clinical}$ Institute for Medical and Chemical Laboratory Diagnostics, Endocrinology, Austria

* Corresponding author

from International Society on Brain and Behaviour: 3rd International Congress on Brain and Behaviour

Thessaloniki, Greece. 28 November - 2 December 2007

Published: 17 April 2008

Annals of General Psychiatry 2008, 7(SuppI I):S220 doi:10.1 186/I744-859X-7-SI-S220

This abstract is available from: http://www.annals-general-psychiatry.com/content/7/SI/S220

(c) 2008 Moser et al.; licensee BioMed Central Ltd.

\section{Background}

Serotonin modulates the activity of the hypothalamicpituitary-adrenal (HPA) axis, to a big part through the serotonin-1A receptor (5-HT1A) [1]. In return, hormones of the HPA axis, namely dehydroepiandrosterone sulfate (DHEAS) [2] and cortisol have regulatory effects on the serotonergic neurotransmission.

\section{Materials and methods}

Eighteen healthy female subjects participated in this PET study. The selective 5-HT1A receptor antagonist [carbonyl-11C]WAY-100635 was used as radioligand. The hypothalamus as an essential part of the HPA axis and eight control regions of interest and the cerebellum as reference region were defined a priori and delineated on coregistered MR images. DHEAS and cortisol plasma levels were ascertained by morning blood collections on the PET day. The 5-HT1A receptor binding potentials of the target brain regions were correlated with DHEAS, cortisol plasma levels and the ratio of DHEAS / cortisol.

\section{Results}

We found highly significant correlations between the hypothalamic 5-HT1A receptor binding and DHEAS $(\mathrm{p}=.003)$ and the ratio of DHEAS / cortisol ( $\mathrm{p}<.0001)$, but not with cortisol and not in other brain regions.

\section{Conclusions}

The 5-HT1A receptor may influence the DHEAS plasma level by modulating CRH and ACTH release as reported for cortisol before [1]. Vice versa, the interaction of cortisol and DHEAS may exert a regulatory effect on the 5HT1A receptor distribution in the hypothalamus as a feedback loop. As disturbances of the HPA axis [3] as well as changes of the 5-HT1A receptor distribution [4] have been reported frequently in affective disorders, future studies should aim their focus on these interactions.

\section{Acknowledgements}

This research was supported by grants from the Austrian National Bank (OENB PI I468) and the Medical Science Fund of the City of Vienna (BMF $\mathrm{P} 25 \mathrm{I5})$ to R. Lanzenberger, and a grant from the Austrian Science Fund (FWF PI6549). The authors are grateful to J. Tauscher, C. Windischberger, A. Becherer, N. Praschak-Rieder, L. Pezawas, M. Willeit, M. Fink, D. Ettlinger, T. Attarbaschi, S. Friedreich, E. Moser, and R. Dudczak for their scientific, medical or administrative support.

\section{References}

I. Pan L, Gilbert F: Activation of 5-HTIA receptor subtype in the paraventricular nuclei of the hypothalamus induces CRH and ACTH release in the rat. Neuroendocrinology 1992, 56(6):797-802.

2. de Kloet ER, Joels M, Holsboer F: Stress and the brain: from adaptation to disease. Nat Rev Neurosci 2005, 6(6):463-75.

3. Christensen MV, Kessing LV: The hypothalamo-pituitary-adrenal axis in major affective disorder: a review. Nord J Psychiatry 200I, 55(5):359-63. 
4. Parsey RV, et al.: Altered serotonin IA binding in major depression: a [carbonyl-C-I I] WAY 100635 positron emission tomography study. Biol Psychiatry 2006, 59(2):106-13.

Publish with Bio Med Central and every scientist can read your work free of charge

"BioMed Central will be the most significant development for disseminating the results of biomedical research in our lifetime. " Sir Paul Nurse, Cancer Research UK

Your research papers will be:

- available free of charge to the entire biomedical community

- peer reviewed and published immediately upon acceptance

- cited in PubMed and archived on PubMed Central

- yours - you keep the copyright 